Новое уникальное издание о М.А. Булгакове

A.V. Zlochevskaya (Moscow, Russia)

\title{
A New Unique Edition on M.A. Bulgakov
}

Всех любителей творчества М.А. Булгакова, а булгаковедов в особенности можно поздравить: вышел в свет 1-й из предполагаемых четырех томов «Аннотированного библиографического указателя» жизни и творчества М.А. Булгакова ${ }^{1}$. Материалы для него сотрудники Отдела научной библиотеки Российской государственной библиотеки искусств начали собирать еще в 1996 г.

Презентация книги состоялась в Музее М.А. Булгакова в рамках VIII Международной конференции «Михаил Булгаков в потоке российской истории XX-XXI веков» (21-22 ноября 2017).

Надо, правда, заметить, что, анонсированное авторами как «первая персональная библиография» автора «Мастера и Маргариты», это издание «первым» в точном смысле слова не является, так как в 2006 г. Справочно-библиографический отдел Библиотеки искусств им. А.П. Боголепова совместно с Управлением культуры ЦАО г. Москва выпустил в свет библиографический указатель «Рыцарь литературы XX века» ${ }^{2}$. Однако эта публикация, конечно, не идет ни в какое сравнение с новым изданием ни по объему (небольшая брошюра в 12 страниц), ни по количеству и качеству информации (всего 102 позиции). И главное принципиальное отличие: Библиографический указатель 2006 г. лишен аннотаций. А между тем не только огромный объем собранного материала, но и информативные и аналитичные аннотации к нему составляют одно из принципиальных достоинств Библиографического указателя 2017 г.

Настоящее издание, бесспорно, является событием в современном булгаковедении, его научную ценность трудно переоценить.

В ходе подготовки этого уникального четырехтомника специалисты РГБИ проделали колоссальный труд. Базой для начального этапа послужили рабочие картотеки, собранные в 1990-е гг. специалистами Российской национальной би-

\footnotetext{
${ }^{1}$ М.А. Булгаков: Аннотированный библиографический указатель. Т. 1: 1919-1940 / Науч. консультант М.О. Чудакова; сост.: М.В. Мишурина, Е.И. Алексеенкова, И.С. Ефимова, Ю.Т. Слизун; ред. С.П. Бавин, М.В. Мишурина; библиогр. ред. А.В. Акименко. М.: РГБИ, 2017. 704 с.

2 Рыцарь литературы XX века (115 лет со дня рождения М.А. Булгакова): Библиографический указатель / Подгот. к изд. Е.С. Забабурина М.: Управление культуры ЦАО г. Москва, Справочно-библиографический отдел Библиотеки искусств им. А.П. Боголепова, 2006. 12 с
} 
блиотеки Д.Б. Азиатцевым и М.А. Бениной. Затем к этому добавились корпусы и списки карточек, оставленных в библиотеках РГБИ в процессе исследований видными российскими булгаковелами: А.А. Ниновым, Б.С. Мягковым, М.О. Чудаковой, Е.А. Яблоковым, Л.М. Яновской и др., а также публикации зарубежных авторов (Э. Проффера, М.К. Отан-Матье, Л. Милн и др.), материалы личных фондов писателя, хранящиеся в Отеле рукописей ГРБ и в Рукописном отделе ИМЛИ, в архивах театров и др. Одной из важных задач издателей Библиографического указателя стала ликвидация множества существующих пробелов в информации о распространении произведений М.А. Булгакова как на родине, так и за границей, и прежде всего о театральных постановках его пьес.

В 1-й том вошли все прижизненные тексты М.А. Булгакова, известные в рукописи или опубликованные, а также театральные постановки и отклики на публикации его произведений в печати (1919-1940 гг.). Всего 3820 позиций. Издание снабжено Указателем имен (стр. 611-643), Указателем заглавий произведений (стр. 644-666), Указателем спектаклей (стр. 667-682) и Списком просмотренных периодических изданий (стр. 683-701). Обнаружена и систематизирована практически исчерпывающая на сегодняшний день информация не только о жизни и творчестве М.А. Булгакова, но и о театральных постановках его произведений, о спектаклях и фильмах. Впервые введены в научный оборот многие библиографические сведения. Работа по сбору информации, ее обработке и систематизации продолжается.

В первой части - «Тексты М.А. Булгакова» - информация обо всем, что рукой М.А. Булгакова было написано и опубликовано при жизни писателя в российской, метропольной или эмигрантской, прессе - не только о художественных произведениях (рассказах, повестях, романах, очерках и фельетонах, заметках, сценариях к театральным постановкам и кинофильмам, либретто опер и др.), но и интервью (с Н.В. Досталем по окончании сценария «Похождения Чичикова, или Мертвые души» // За большевистский фильм. М., 1934. № 22 (25 авг.). С. 3; «Он был велик и неудачлив» - в связи с премьерой «Мольера» на сцене МХАТ // Горьковец. М., 1936. № 3. 15 февр. С. 2 и др.), а также о переводе комедии Ж.Б. Мольера «Скупой» (Мольер Ж.Б. Собр. соч.: В 4 т. Т. 3. Л.: Гослитиздат, 1939. С. 371-497) начиная статьей «Грядущие перспективы» в газете «Грозный» (1919. № 47. 13/26 нояб. С. 2) и заканчивая последним прижизненным изданием - сценарием театральной постановки «Дон Кихота» для театра им. Вахтангова (М.: Отдел распространения ВУОАП, 1940. 81 с.).

Материал, представленный в этом разделе, позволяет осознать масштаб и интенсивность креативной энергии писателя, а еще более изумиться тому, как в разгар изнурительной поденщины ради хлеба насущного в газетах «Гудок», «Рабочий», «Рупор» и др. могли рождаться такие поистине бриллианты художественной словесности, как «Неделя просвещения», «Записки на манжетах», «Ханский огонь», «Дьяволиада» и даже такой шедевр, как «Белая гвардия». При этом нетрудно заметить, что лучшее поначалу выходило в свет по большей части за рубежом - в Берлине, Париже, Риге, Софии, Нью-Йорке и др. Читатели моего поколения помнят: со многими булгаковскими произведениями - «Собачье сердце», «Дьяволиада», «Бег» и др. - мы познакомились в «самиздате» - репринтах зарубежных изданий.

Вторая часть - «Публикации о жизни и творчестве М.А. Булгакова» - не только отклики на публикации писателя в СССР и за рубежом, но также и документы, 
связанные с общественной жизнью писателя: разрешения / запреты публикаций произведений или постановок пьес и др.

В целом 2-й раздел 1-го тома воссоздает весьма полную картину жизни М.А. Булгакова, со всеми ее коллизиями и перипетиями.

Удивительно, как далеко разошлись мнения публики и критиков о пьесах М.А. Булгакова. «Почин» был положен уже первым известным критическим отзывом - статьей П.П. Голодолинского «На развалинах социальной революции. Ответ на статью М.Б. “Грядущие перспективы” (Грозный. 1919. №49. 15/28 нояб. C. 2). Так что Елене Сергеевне, обладай она возможностями Маргариты, пришлось бы разгромить слишком много квартир на просторах Советской России.

Положительные отклики крайне немногочисленны: отзыв В.Ф. Переверзева о «Дьяволиаде» (Печать и революция. 1924. Кн. 5. С. 134-39), рецензия А.К. Воронского на первые две части «Белой гвардии» и на «Роковые яйца» (Красная новь. М.; Л., 1925. Кн. 10. С. 254-265), отзыв Ю.В. Соболева о «Роковых яйцах» и «Дьяволиаде» (Заря Востока. 1925. 13 марта. С. 6) и немногие др.

Разумеется, оценки эмигрантской критики были более доброжелательны, но, надо признаться, не на много (Берберова Н. Литературная летопись // Возрождение. 1929. 16 мая; 6, 13 и 25 июня; Осоргин М.А. «Дни Турбиных»: Мих. Булгакова // Последние новости. 1927. 20 окт. С. 3 и др.).

Информация о мало знакомых российскому читателю зарубежных критических отзывах о произведениях писателя и постановках его пьес на сценах Европы и США (Г. Адамовича, Ю. Айхенвальда, В. Амфитеатрова, В.И. Горянского, М.А. Осоргина, В. Ходасевича и др.) особенно ценна. Замечательна по своей проницательности догадка В.А. Амфитеатрова: в рецензии на «Роковые яйца» (Возрождение. 1925. 13 июля. С. 3) он пишет, что «нелепый финал» повести был, вероятно, написан по требованию советской цензуры.

Полноценное представление получит читатель Библиографического указателя о полемике вокруг «Белой гвардии» и знаменитого мхатовского спектакля «Дни Турбиных». В советской прессе роман, а спектакль в особенности, получил, как известно, оценку исключительно «ругательную». Весьма симптоматична информация, приведенная в аннотации к монографии В.И. Блюма ““Любовь Яровая” на сцене Московского Малого театра» (М.; Л., 1940). Автор книги повторил вслед за А.В. Луначарским (Два спектакля // Заря Востока. 1927. 6 марта. С. 5) ставшее у советских критиков традиционным противопоставление «Любови Яровой» «Дням Турбиных»: первая - ответ на «злобную контрагитацию» булгаковской пьесы. И вот интересный эпизод из театральной жизни 1920-х гг.: «Отсутствие в окончательной редакции пьесы К. Тренева роли мужа Пановой - из-за сходства с Алексеем Турбиным, персонажем с “подмоченной репутацией”» (стр. 592).

Неприятие у советских критиков вызывало всегда одно - не «наша» идеология автора «Белой гвардии». И здесь они были абсолютно правы: Булгаков, как один из его любимых героев профессор Преображенский, «не любил пролетариат». Хотя и был, как ни удивительно, лоялен Советской власти. Последнее обстоятельство особенно раздражало критиков эмиграции (Ходасевич В. Смысл и судьба «Белой гвардии»// Возрождение. 1931, 17 дек. С. 3). Они тоже хотели четкой, но только противоположной советской критике, идеологической позиции: чтобы большевики были показаны ужасными, а белые прекрасными. Булгаков не мог удовлетворить ни тех, ни других. Надо, впрочем, признать, что в прессе со- 
ветской, как и в эмигрантской, неизменно отдавали должное таланту писателя и художественным достоинствам его произведений.

И здесь напрашивается замечание структурного характера: желательно четкое разделение советской и эмигрантской критики. Так читателю было бы удобнее ориентироваться и сопоставлять зарубежную и метропольную прессу.

Безусловный интерес представляют собранные в Указателе сведения о рассказах актеров театра и кино, участвовавших в пьесах М.А. Булгакова, в спектаклях и фильмах по его сценариям (О.Н. Андровская, В.Г. Сахновский, Н.П. Хмелев, Н.К. Черкасов и др.), а также режиссеров и композиторов, писавших музыку к спектаклям и фильмам, - О.Ф. Глазунова, П.А. Маркова, И.М. Рапопорта, Р.Н. Симонова, К.С. Станиславского, Т.Н. Хренникова и др.

Издание адресовано исследователям не только творческого наследия М.А. Булгакова, но и истории литературы и театра, а также преподавателям вузов, аспирантам, студентам, специалистам архивов, библиотек и музеев - всем интересующимся творчеством писателя.

Для всех булгакофилов эта книга, погружающая нас в мир великого русского писателя, безусловно, станет увлекательнейшим чтением.

Сведения об авторе:

Алла Владимировна Злочевская,

доктор филол. наук

ст. научный сотрудник

филологический факультет

МГУ имени М.В. Ломоносова
Alla V. Zlochevskaya,

Doctor of Philology

Senior Researcher

Philological Faculty

Lomonosov Moscow State University

zlocevskaya@mail.ru 